\title{
Being Lucky. Transmedia and Co-Creation Practices in Music Video-Clips
}

\section{Gemma San Cornelio - Antoni Roig Telo}

Universitat Oberta de Catalunya, Spain

doi: 10.7358/ijtl-2015-001-sanc

gsan_cornelio@uoc.edu - aroigt@uoc.edu

\begin{abstract}
In this paper we will deal with music related co-creation practices from the perspective of transmedia literacies. We will take as a case example "Evolution of Get Lucky", a collective experiment by musician PV Nova, that consisted in taking one of the most popular pop songs of 2013, Daft Punk's Get Lucky, re-interpreting it through the conventions of different musical decades and inviting users to playfully build the pieces of a participatory music video. "Evolution of Get Lucky" is a perfect opportunity to reflect on transmedia literacies, as well as on appropriations of popular culture, the social shaping of music memory and the notion of nostalgia. Our approach to the case study will be informed by our previous work on participatory culture and co-creation practices.
\end{abstract}

Keywords: co-creation practice; transmedia projects; remix; re-appropriation; crowdsourced music video; cultural nostalgia; Get Lucky.

\section{INTRODUCTION: RE-ENGAGING THE MUSIC FAN}

Since the beginning of the steady decline of control over recorded music in the late nineties, the music industry has felt under a continuous strain to re-invent itself, in parallel with the emergence of new cultural practices that, in different ways, have been challenging its copyright-based business model. Even if digitization and the popularization of online music file sharing (particularly of compressed sound files in $\mathrm{mp} 3$ standard) have signified a radical paradigm shift in terms of the business of the recorded music industry, controversies on 
the legal limits regarding music fan practices go back, at least, to the explosion of home tape recordings from the mid-seventies ${ }^{1}$. (Jacobson 2010, 41; Karaganis, 2011, 41-45 Benkler, 2011, 749)

The main challenges contemporary recording music industry is facing can be broadly summarized in two: on the one side, it is the first cultural industry where specific technocultural changes occur, like the popularization of an industrial standard, the $\mathrm{mp} 3$ format, for file exchange and mobility, due to its high ratio of popularity versus portability of compressed files (see Sterne 2006). On the other side, changes in consumer practices lead to changes of recorded music as a cultural commodity: digitization processes, but also new cultural practices force to re-introduce added value and to re-think the materiality of music (see Bull 2007; Magaudda 2011).

Dramatic sales drop of recorded music while, paradoxically, musical consumption is growing, have forced the industry to try apparently contradictory strategies, like enhancing the objectual nature of music (through collectable editions of recordings) or the 'immaterial' nature of music in the search of new markets (embracing digital downloads usually attached to DRM solutions, or ringtones) (see Rushtin 2013, Bustinza et al. 2013, Díaz 2013). Interestingly, some different strategies in both trends have been progressively adopted, after acknowledging the consolidation of certain consumer practices in a bottom up fashion. This is the case of vinyl editions, streaming social services or free downloadable tracks. Thus, it is more and more common to premiere new tracks from renowned artists via social audio and video sites like Youtube or Soundcloud, or even full album streaming for free, for a limited time.

It is important to note that different artists, new and renowned alike, have experimented with different ways to reconsider their relationship with their public. This way, closer ties between artists and fans are established, with less mediation - at least apparently - from music labels, thanks to the sense of personalization and intimacy awarded by social networks. A paradigmatic case is MySpace, which steadily became a music-related social network for - mostly - independent artists. We must also mention Bandcamp, a social platform and online music store that connects independent bands (and more recently, also indie game developers) with fans. Anyway, big record labels have found different ways to promote their top artists taking advantage of new consumption patterns, particularly among their younger market. This is the case of the popular music video streaming service Vevo, a joint venture of Universal Music Group, Sony Entertainment Group, Google and Abu Dhabi

1 A classic example is the British campaing 'Home tape is killing music' in the mid-eighties. See: http://www.theguardian.com/music/2008/jun/17/popandrock; http://cbswnewhd.wordpress.com/2009/ 02/12/rock-101-home-taping-is-killing-music/.

International Journal of Transmedia Literacy - 1.1 - December 2015

http://www.ledonline.it/transmedialiteracy/ 
Media ${ }^{2}$ presented as a sort of "brandless brand" ${ }^{3}$, thus securing streaming revenues and viral promotion of top artists and celebrities in social media. This last example shows that, many times, engagement and participatory discourses adopt the form of co-option, which forces us to take into account the contradictory and nature of industry-led discourses on creative participation.

In this paper we will deal with music related co-creation practices from the perspective of transmedia literacies. We will take as a case example "Evolution of Get Lucky", a collective experiment by PV Nova, a renowned French musician, composer, comedian and YouTube celebrity. For this experience, PV Nova took one of the most popular pop songs of 2013, Daft Punk's Get Lucky, re-interpreted it through the conventions of different musical decades and invited users to playfully build the pieces of a participatory music video, thus mixing music, interactivity, video, CGI, play and performance. Although it can be considered as a one-off participatory experiment, "Evolution of Get Lucky" is a perfect opportunity to reflect on transmedia literacies, as well as on appropriations of popular culture, the social shaping of music memory and the notion of nostalgia. Moreover, our approach to the case study will be informed by our previous work on participatory culture and co-creation practices.

Regarding this specific kind of participatory phenomena, our main objectives can be stated as follows:

- To identify the participatory dimensions of a music video project with transmedia qualities.

- To analyze the aesthetics of a crowdsourced music video project.

- To consider the role of remix practices as a form of literacy (Manovich 2005; Lessig 2005; Jakobson 2010)

- To analyze the features of playful re-appropriation of pop history through co-creation, connecting to different notions of cultural nostalgia.

\section{EVOLUTION OF GET LUCKY AS A PARTICIPATORY PROJECT}

There are some features that allow understanding Evolution of Get Lucky as a participatory project and consequently to be connected with our previous research regarding creative practices and processes that invoke some sort of participation and even co-creation. Some of our preceding work has been

2 This involves two of the three main record labels, leaving out only Warner Music Group, which has established a partnership with MTV.

3 It is interesting to note that there is no mention of this partnership in the VEVO website, not even in the 'About' section.

International Journal of Transmedia Literacy - 1.1 - December 2015

http://www.ledonline.it/transmedialiteracy/ 
related to several cultural practices, such as modding, photography creative communities, fanworks, participatory filmmaking (crowdsourcing and crowdfunding), or DIY video production amongst others. This previous experience has allowed for identifying, firstly, the necessary conditions of participatory projects; in other words, what are the key features that need to be assessed in participatory-related projects. Secondly, the desirable conditions for participatory projects, which force us to distinguish between rhetorical discourses on the supposed participatory qualities of a project and the actual participation processes. In several occasions, there is a notable distance between participatory promises and its actual deployment.

Beyond these general rules for participative projects we have critically analyzed the different approaches to co-creation, connecting them with the notion of innovation in new media (San Cornelio and Gómez Cruz 2014) and the conditions for co-creation in creative communities, more specifically interested in labor issues and informal markets, as well as the emergence of affective economies and new business models (Roig et al. 2013). Through an ethnographic approach we have particularly attended to conflict and negotiation, motivations and rewards in participatory creative processes (DIY/fandriven creative practices in production, financing and distribution) taking into account that there is an industrial interest in the 'crowds' and DIY production (co-option).

According to the previous considerations it must be stated that Evolution of Get Lucky is a participatory project as long as it has some pre-defined rules, which consisted mainly in an open call for videos based on the different decades represented in the music track that the musician PV Nova produced on purpose for the project. The call involved creative visual freedom to interpret and represent visually the variations produced in the sound track according to PV Nova arranging and remix work. In this regard, the field of action for participants is quite clear and limited. Another rule for participation in the project is that it is an open call (to everyone) with a tight deadline. And once the videos are uploaded and received by the musician there is neither a decision-making process on the videos, nor a contest. PV Nova took the responsibility to decide which videos would be included in the final remix, ending up in a linear and closed edition process.

On the other hand, considering other previous co-creation examples, there are other important features that can also be observed in Evolution of Get Lucky, such as the notion of expertise, which is relevant as long as different kinds of literacies come into play: video producing skills are needed in order to elaborate videos with a quality standard, but also the capacity of the materialization of visual ideas, be it in the form of a narrative, through appropriation of visual and cultural codes related past decades - which introduce the topic of 
the social construction of nostalgia and questions related to authority -, and, finally, projections of imagined futures.

Another important point in co-creation and more especially in transmedia projects is the notion of 'experience', as users are invited to participate in a singular and playful event, marked by a very specific timeline and where creative freedom and authorial control are combined through crowdsourcing processes (Roig 2013; Leivobitz, Roig and Sánchez-Navarro 2012). Thus, this affective experience activates a strong sense of belonging, as participants contribute actively to produce and enhance some of their favorite cultural products, at the same time global and local. In this regard, Evolution of Get Lucky constitutes a very engaging project that contributes to feed the main product of Get lucky by Daft Punk (and all that this means in terms of expanding the iconic power of the band) and at the same time projects the work of the artist PV Nova, whose presence on the web is quite significant, especially within the French context.

Taking into consideration some particularities of user-generated content made by fans, such as connection to a canon, strong affectivity and collective gatekeeping, this project constitutes a clear example of how transmedia and participation can be applied to engagement in creation processes. It is important to note that in the context of this article, we understand canon ${ }^{4}$ as the set of basic rules that must be respected in order to maintain a connection between a derivative, or transformative work, to the original source text (Buse and Helleckson 2006). In the framework of fandom, for instance, its is expected that fanworks respect key features regarding characters (physical and psychological treats, development), world coherence, visual aesthetics, critical story points and narrative development, etc. Put it in other words, canonicity is closely connected to a notion of authorship and authority coming from the original materials that are being subjected to different sorts of expansions and reworking. This is not to say that canon remains inalterable, but even canon transgressions, like crossovers with other cultural products, alternative events, changes in character definition (like sexual preferences) or spoofs are always valued in relation to canon. In the case of relevant fanworks that depart from the original canon in some ways but become highly valued by fan communities, they can constitute a new 'secondary' canon - called sometimes fanon -, which at the same time established new rules to be followed in this specific branch of fan creativity.

${ }^{4}$ In the field of music and other arts, 'canon' acquire slightly different meanings, tied to aesthetical normativity or representativity of an era or an artist's body of work. A starting point for discussion can be found in Tieste (2009): http://www.cinetecadelfriuli.org/gcm/allegati/Collegium_Papers_2009. pdf\#page $=102$

International Journal of Transmedia Literacy - 1.1 - December 2015 http://www.ledonline.it/transmedialiteracy/ 
In this case, we have to consider as canon the original recorded version of the song in relation to PV Nova's cover, but on the other side, the new rules introduced by the Evolution experience can be considered as a secondary canon, asking the participants to fit into the conventions of each decade included in the song, which becomes essential for the success of the transmedia playful experience.

\section{Case Study: Evolution of Get LuCKy}

\subsection{Description of the project}

Get Lucky is a pop song by French duo Daft Punk, and was the leading single of their 2013 album Random Access Memories. Already popular for blending of pop, rock, funk, classic synthesizer and contemporary dance music, for Random Access Memories Daft Punk were particularly ambitious in combining the new and the old, electronic and live instruments, thus featuring multiple stellar collaborations like guitar player and producer Nile Rodgers (leader of groundbreaking seventies band Chic and sought-after producer in the late seventies and eighties), Giorgio Moroder (considered the pioneer of the introduction of modern synthesizer in pop music and movie soundtracks) and singers as diverse as Julian Casablancas (from punk rock band The Strokes) or hip-hop and Rhythm \& Blues star Pharrell Williams. In fact, Williams sang and co-wrote with Nile Rodgers - together with the Daft Punk members - the song Get Lucky.

Beyond musical qualities and popularity, all these references are important as they showcase the confluence, in the Daft Punk world, of diverse temporal and stylistic influences ${ }^{5}$. This is made particularly evident in Random Access Memories, starting from the album title and through explicit homages and gestures to their heroes: thus, the introductory section of the song "Giorgio by Moroder" is two minute monologue by the man himself telling the story of his beginnings in the music business, before the actual instrumental song takes over (there's still a further short spoken section on freedom of creation in music).

I wanted to do an album with the sound of the 50's, the sound of the 60's, of the 70's and then have a sound of the future. And I said, "Wait a second... I know the

5 Daft Punk even came to compose the soundtrack for the movie Tron: Legacy (2011), the sequel to a classic cult film from the eighties, Tron (1982), famous for its visual game-like aesthetics 
synthesizer - why don't I use the synthesizer which is the sound of the future?" And I didn't have any idea what to do, but I knew I needed a click so we put a click on the 24 track which then was synched to the Moog Modular. I knew that it could be a sound of the future but I didn't realise how much the impact it would be. (Excerpt of the spoken section of Daft Punk's song Giorgio by Moroder 2013)

It can be said that, randomly or not, the 'memories' scattered across the whole album show a very specific approach to nostalgia, a nostalgia for an ideal of creative freedom. In a sense, these introductory words have been an inspiration for the experiment we are going to analyze.

Along the 2013 Get Lucky has constituted one of the most popular songs of the year, both in commercial environments and in more selected ones. Actually, a specific sign of this popularity is the number of versions, covers and remixes that take the song has produced ${ }^{6}$. Evolution of Get Luky, then, would be one of those tributes, but adding some complexities derived from the fact that is a participative project.

\subsection{PV Nova Profile and his 'experiences'}

Just like Daft Punk, the driving force behind our case study, PV Nova, can be defined for being a notably restless and eclectic character. A member of French music and comedy theatre company Les Tistics, as well as composer and multiintrumentalist (he released a studio album, Start Again, in 2011, available for free in his website), he is notably known by his YouTube page, where he posts remix and studio work and, particularly what his - mostly - one man shows called 'Experiences Musicales'. With a distinct humoristic style, PV Nova experiments and plays (with) different music styles and eras. Although Evolution of Get Lucky is not counted among PV Nova's experiences, it is closely connected to them, as he reproduces completely different styles around the same composition, adding an important twist: user participation and engagement in a transmedial treat.

As can be observed in the Figure 1, the project took place in less than two months, in spring/ summer of 2013. The kickoff event was the release of an interactive video showing a continuous version of the Get Lucky song spanning a whole century decades, starting in the 1920s and ending in the 2020s. At the end of the video, PV Nova explains the rules of the participatory proposal, inviting users to shoot their own visual representation of any decade of their choice and upload it to Youtube. With all the material available, mostly created

6 http://www.huffingtonpost.co.uk/2013/06/12/daft-punk-get-lucky-evolution_n_3426277. html\#slide $=2591696$

International Journal of Transmedia Literacy - 1.1 - December 2015

http://www.ledonline.it/transmedialiteracy/ 
by French users, PV Nova selected and edited a linear version, premiered in early August, 2013. (Figure 1)

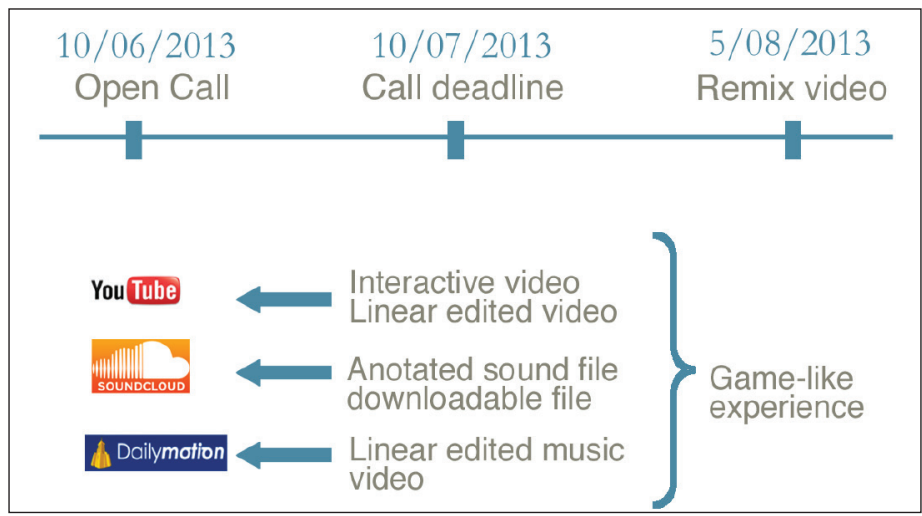

Figure 1 - Evolution of Get Lucky. Project timeline and transmedia elements.

\section{DiSCUSSION OF THE CASE STUDY}

Taking into account the previous considerations, the research has been organized around an analysis that focuses on the material aspects of the audiovisual project and on the actors from a triangulated perspective that includes, the artist who fosters the project, the participants involved in it, and some audience reactions to it. What is presented in this paper is the first phase of the analysis, which involves the set of videos received during the call as the main source of our research. Videos are considered both as independent pieces and part of the whole project Evolution of Get Lucky.

Firstly, we have proceeded to perform a visual and aesthetics analysis of the videos, looking at the cultural references that each video seems to contain. In this regard we focused specially in the videos selected for the final cut. On the other hand, we were interested in different levels of participation in the call, thus identifying the most successful decades, in terms of the amount of videos received corresponding to each decade. Secondly, we have taken into account the information available in the sharing platform, in this case YouTube, in terms of comments, feedback, views, etc. as well as the comments that the project has generated in other platforms and forums. Additionally, a set of interviews with the artist and some of the participants has been initiated, but for the purpose of this edited issue, interviews will be part of the second 
phase of the research, and here we will focus mainly in the audiovisual part of the project, which is more related to the notion of transmedia and its possible derivations in terms of literacies.

\subsection{Audience participation: some figures and aesthetic notes}

Considering the tight deadline suggested, only a month, it might be stated that the call was quite thriving. Regarding the audience participation, the amount of videos presented were 179 in total, although only 137 videos are publicly available. Within this sample, only 38 videos were selected for the final remix, from 33 different contributors. That means that some of the participants posted more than one video, like in the case of participants Art Kitetisse, Artallowsall or Jasmine Seguin.

After undertaking an initial observation of the whole set of videos, we could perceive that the quality of videos was to a certain extent unbalanced, being some of them almost professional works and others just a playful attempt. (Figure 2)

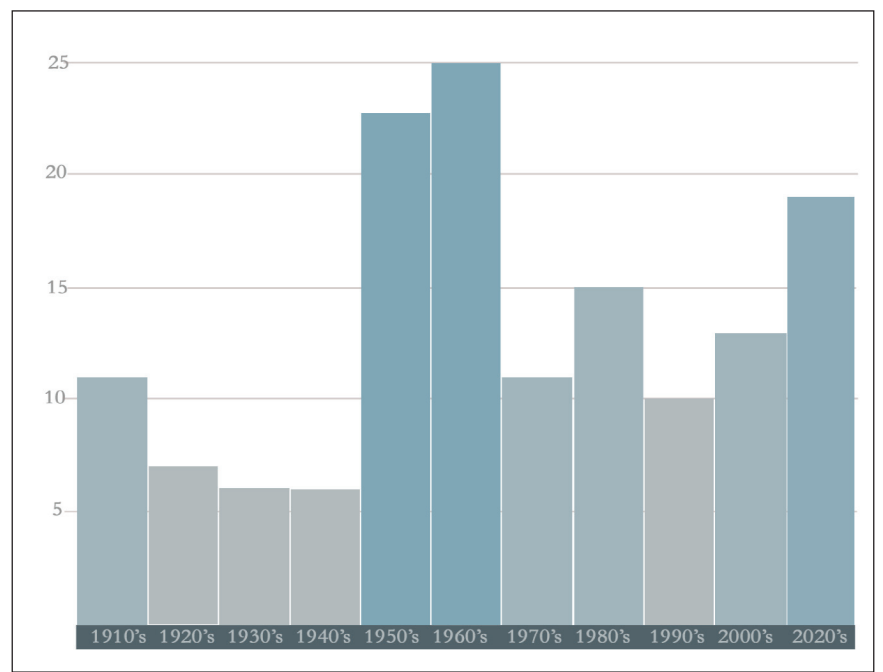

Figure 2 - Amount of videos posted by participants by decades. Source: authors

Considering the amount of videos posted, as the figure 2 demonstrates, the most successful decades are, by far, the 1960's and the 1950's, and in second term, followed by the 2020's. This is an interesting result, since our original hypothesis, based on viewing the final cut and the average age of the partici- 
pants in the videos (most of them in their twenties), was that the most representative clips should be placed in the 80 's or 90's. Nevertheless, a primary interpretation of the different levels of participation in each decade illustrates both nostalgia and projection to the future. Of course, the challenge involved turning back to the past to interpret a present-day popular music hit, but it is interesting to remark that the materials received for both decades (50-60) almost double the rest of decades. This predominance is probably connected with the centrality of both decades in our contemporary history; the years that followed the Second World War generated a lifestyle represented in an elevated amount of visual materials and references available in films and music likewise. Accordingly, nostalgia ${ }^{7}$ is one of the central formulations related to postmodern aesthetics (Jameson 1990) which revolved precisely in cultural interpretations of those years in cinema and other audiovisual forms (Denzin 1991, 69).

More specifically, in musical terms, a connection with the notion of 'Retro music' could be elaborated. For some authors 'Retro' evokes always the relatively immediate past; mainly stuff that happened in living memory, but, according to Elizabeth Guffey (2006), retro does not refer to all historical periods; it only applies to the recent past, in particular the years after the Second World War. Following the observations made by Cartwright, Besson and Maubisson) people have tastes for pop-rock music that was most popular early in their lives or even before birth. It is interesting that people show a preference for pop-rock music that was released prior to their timeline (2013, 463). In this sense, Reynolds (2011) argues the self-revolutionizing musical innovation that marked the second half of the twentieth century is so largely exhausted that artists are now primarily in thrall to the past.

Evolution of Get Lucky is an example of this process of looking back to the past, which, as previously stated, is also present in the original track and the whole record by Daft Punk. In this regard the suggestion of opening a means of visual interpretation of the different decades, rather than providing with different images of each decade, has produced quite homogenous aesthetics. Most of the videos of the 50's presented similar features, including iconic images such as the poster by Howard Miller's "We Can Do It!" poster from 1943, which is reinterpreted in several videos. (Figure 3)

7 The author argues that nostalgia facilitates the continuity of identity and provides three working hypotheses as to the meaning of nostalgia. Wilson $(2005,19)$ writes that: $(1)$ nostalgia is an interpersonal expression of self which subjectively provides one with a sense of continuity; (2) nostalgia is an interpersonal form of conversational play, serving the purpose (3) nostalgia is a form of idealizing or mystifying the past; and (4) nostalgia can be used as a cultural commodity derived from the experience of a particular age-cohort and transformed into a particular market segment.

International Journal of Transmedia Literacy - 1.1 - December 2015

http://www.ledonline.it/transmedialiteracy/ 


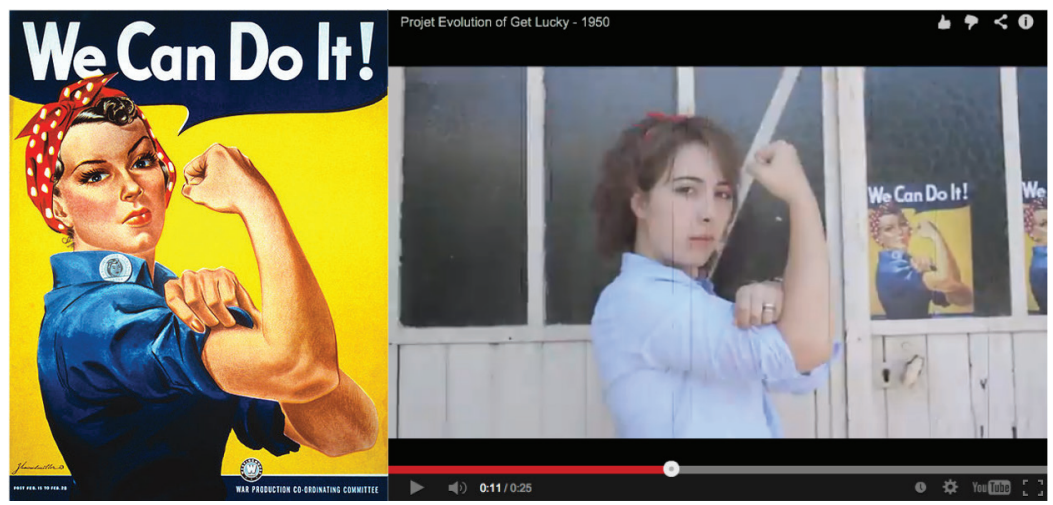

Figure 3 - Iconic references to the 50's.

Nevertheless, the maximum level of uniformization is shown with the videos corresponding to the decade of the 60's, that include psychedelic references, nature and hippies in most (all) of them. It could be stated that the main source of influences for the performances related to this decade are the big music festivals of the late sixties, like the Woodstock Festival (explicitly featured in one of the videos through fragments of the Michael Wadleigh documentary). Some iconic images, like the Beatles' Abbey Road album cover are also featured. (Figure 4)

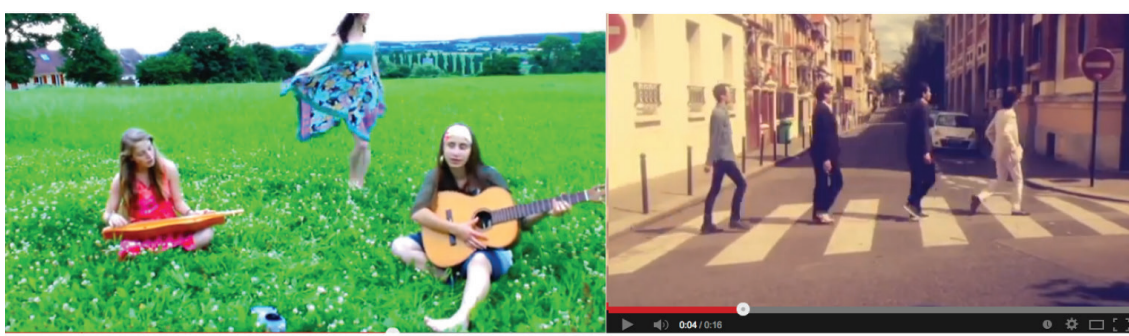

Figure 4 - Iconic references to the 60's.

The decade of 2020's, that corresponds to our near future, it is also visually quite homogeneous, but in this case presenting abstracted, post-apocalyptical scenarios and an excessive use of image filters and CGI in many of them. The speculative nature and the lower quality of these videos are probably the reasons why only two of them were selected for the final cut.

Curiously, considering our initial appreciation, the 70's, the 80's and the 90 's are less productive decades, regarding the amount of videos produced and 
sent by the participants. Nevertheless, it is remarkable that most of the videos received - especially the selected ones - capture accurately the musical clues present in the audio remix made by PV Nova, (which are quite recognizable, by the way). This is very visible in the seventies, represented by disco music, and the eighties reproducing the aesthetics of very popular synthpop bands, such as Depeche Mode, Devo, John Foxx, Tears for fears, or Soft Cell. In these cases, the visual interpretation seems to be more influenced by the musical base remix than by the historical, cultural and musical references regarding a specific decade (for instance, very popular artists from the 80's like Michael Jackson or Madonna are not present).

In this regard, it is quite notable that the decades more distant to our times (20's, 30's and 40's) are represented according to cinema images, rather than its corresponding musical styles, which we assume that are more difficult to identify for a presumable young audience.

Another relevant focus of attention in our analysis has to do with unexpected user appropriations, in some places transgressing the rules. For example, there are seven users that decided to interpret the whole array of decades, instead of choosing one, and consequently did not follow the instructions of PV Nova, choosing to use the musical base for a different purpose. One significant case is a video where PV Nova's work is synchronized to fragments of musical movies from different eras in a mashup fashion. In another interesting example, the author chooses a representative movie per decade, mostly French examples like experimental silent film La Coquille et le clergyman (1928), Les Dames du Bois de Boulogne (1945), Tatie Danielle (1990) or Le secret de Kells (2009), along with renowned British and American films, like Jesus Christ superstar, The knack... and How to Get It, Tootsie or Slumdog Millionaire.

An additional minority but noteworthy trend consists in building a selfcontained story in the video into a story, sometimes spanning more than a decade, sometimes playing with a single decade version but in the bigger framework of a short story. Again, this form of appropriation tends to be well received in terms of views and reception. In the cases where users made their work fit into a decade, as stated by the rules, they were mostly selected for the final cut.

\subsection{Feedback and responses}

Other interesting ideas could be reported after examining the data related to the participants, number of visualizations, the most popular videos and the nature of comments to the videos. As for the comments, it is interesting to note the differences stated depending on the decade, that is, the affective distance 
and engagement of the followers. In the case of videos set in the earlier decades, comments tend to make reference to the aesthetic 'look and feel' of the visual representation, that is, unrelated to musical motives. From accuracy of clothes, ambientation, technology or even visual filters applied to reproduce accordingly the visual codes of the times, to connections to celebrities like Charlie Chaplin. In the fifties, new motives appear again related to authenticity - there are mentions to microphone and guitar models, for instance-. In the sixties, there are two relevant new noticeable findings: there is no discussion on the canonicity of hippy flower power; additionally, fandom discourse shows up in the way The Beatles are referred (highlighting the detail of having one of the actors re-staging the Beatles crossing the pedestrian crossing for the Abbey Road album cover, barefooted, just as Paul McCartney). In the 80s, there are multiple references to standout artists considered as representative, from Depeche Mode to Kraftwerk or Indochine (one of the few references to French artists). In the nineties, references to visual style and editing are mentioned, showing the importance given to music video aesthetics. As for the contributions connected to present and the near future, comments are related to identifying cultural references and technical skills (there are for example more filter effects, animation and Computer Generated Images).

Finally, it is interesting to highlight that there are several positive user comments implying that a participant's video 'should be winning' and that they would 'vote for them', which is at odds with the playful rules of the project (PV Nova never stated any voting process in the project rules), and at the same time shows a familiarity with this sort of contest-based crowdsourced efforts, that tend to be mistaken as participatory per se.

Another space we have analyzed is the forum track "Daft Punk's Get Lucky evolution throughout the ages" in the site Reddit ${ }^{8}$, devoted to comment the original music remix Evolution of Get Lucky, that is the interactive video - without images - that contained the music that originated the call for participation. The conversation started the $11^{\text {th }}$ of June 2013 and has generated a total of 580 comments.

A general overview of the comments reveal a quite enthusiastic reception of the project, where each participant expresses his or her preferences regarding the decade they like most. At the same time they identify different influences in the music track according to their personal observations. An example of that is the sound of the 2020's, which is identified with the band The Glitch Mob, as well as the 2000's part is thought to be influenced by Aphex Twin or Skrillex.

$8 \mathrm{http} / / /$ www.reddit.com/r/videos/comments/1g40pf/daft_punks_get_lucky_evolution_throughout_the_ages/. 
Beyond the 'external' influences that PV Nova is supposed to tribute, the conversations in the forum sometimes turn to reflections on the nature of the remix and the music of Daft Punk. In a sense, they are reflecting on the adherence of PV Nova to the 'canon' of Daft Punk, since most of the comments say that the different parts of the remix remind to previous records of the band.

More interestingly, the conversations in the forum in different moments focus on one of the main topics we had previously expressed in our analysis: nostalgia. Here we can read two examples:

Maybe in contrast to today's pop music, but kids in the 70's and 80's fucking hated the genre. I HATED pop music of the 90's and 00's, yet there was this nostalgic 90's compilation that hit the front page a few months ago, and there were people commenting on how great the pop songs were! We keep settling for less, it is going to be bizarre in 20 years when we speak of the glory days of Keisha and Skrillex. (powercorruption)

People like being nostalgic about stuff, even if it was rubbish at the time. (elpielan)

For participants in the forum the notion of nostalgia is then something inherent to human nature, supporting the ideas of Cartwright, Besson and Maubisson (2013). Moreover, regarding music two types of nostalgia are identified: the one that is present in the music we have lived (and consequently the one we will defend as the best one), which is expressed in the forum, and the nostalgia of past times that we have not lived, but have been described as the greatest, and consequently we all wish to have lived in terms of music (expressed in the videos).

\section{CONCLUSIONS}

After considering the results of the video remix that PV Nova presented and the rest of videos sent by the audience it must be stated that Evolution of Get Lucky is a crowdsourced project with some unique features and a few participatory elements. In this regard, it is a closed proposal and a personal project of the artist, which is at the same time very iconic. Regarding the rules, the crowdsourcing is restricted to the video and does not involve the music, which has been previously remixed by the artist. Rules for participating are in this sense very strict, even if there is still some room for different forms of re-appropriation and transgression. In this sense, exploring motivations for participants in crowdsourcing can help modelling successful experiences, which be further explored in future research.

In terms of aesthetics, collaboration this is not necessarily connected with fragmentary or differentiated interpretations, rather, this case demonstrates the 
contrary: in many cases, there is an aesthetic uniformization related to cultural interpretations and visual and musical clues.

Considering to the most popular decades, nostalgia and projections of future seem to be equally motivating cultural interpretations. In this sense, it is curious for us the scarce presence of local cultural (French) references in the videos, abounding North American or British influences in most of the decades.

In a more general sense, it can be stated that crowdsourcing connected with transmedia (through remix, or other strategies) can be used as a powerful tool in literacy, e.g. exploring the relations between music and images, and how they influence each other. Producing and remixing music videoclips in a collective way, puts on the table questions of styles and expertise, producing creative re-appropriations and expressions of authority enacted through notions of nostalgia and authenticity.

\section{REFERENCES}

Benkler, Yochai. 2011. "Networks of Power, Degrees of Freedom." International Journal of Communication 5: 721-755.

Bull, Michael. 2007. Bergson's iPod? The Cognitive Management of Everyday Life'. Sound Moves: iPod Culture and Urban Experience. London: Routledge.

Hellekson, Karen, and Kristina Busse. 2006. Fan Fiction and Fan Communities in the Age of the Internet. Jefferson, North Carolina: McFarland.

Bustinza, Oscar F. et al. 2013. "Music business models and piracy." Industrial Management and Data Systems, 113: 4-22.

Cartwright, Phillip. A., Ekaterina Besson, and Laurent Maubisson, 2013. "Nostalgia and technology innovation driving retro music consumption." European Journal of Innovation Management, 16(4): 5.

Denzin, Norman K. 1991. Images of postmodern society: Social theory and contemporary cinema. Vol. 11. London: Sage.

Diaz, Angel. 2013. Dígitos que sueñan con pureza analógica. Fans del sonido ante las nuevas técnicas de producción musical. Unpublished working paper. Barcelona: Internet Interdisciplinary Institute.

Guffey, Elisabeth. 2006. Retro: The Culture of Revival. London: Reaktion Books,.

Jakobson, Erik. 2010. "Music remix in the classroom." In DIY media: creating, sharing and learning with new technologies, edited by Nobel, M. and Lankshear, C. New York: Peter Lang Publishing.

Jameson, Fredrick. 1990. Postmodernism, or, the Cultural Logic of Late Capitalism. Durham: Duke University Press. 
Karaganis, Joe. 2011. "Rethinking media piracy." In Media piracy in emerging economies, edited by Karaganis, J. New York: The Social Science Research Council.

Lessig, Laurence. 2005. Por una cultura libre: cómo los grandes grupos de comunicación utilizan la tecnología y la ley para clausurar la cultura y controlar la creatividad. Barcelona: Traficantes de sueños.

Magaudda, Paolo. 2011. "When materiality 'bites back': digital music consumption practices in the age of dematerialization." Journal of Consumer Culture 11 (1): $15-36$.

Manovich, Lev. 2005. Remix and remixability. Rbizome. Retrieved from www.rhizome. org/discuss/view/19303.

Reynolds, Simon. 2011. Retromania: Pop-rock Culture's Addiction to its Own Past. London: Faber\&Faber.

Roig, Antoni, Gemma San Cornelio, Elisenda Ardèvol, and Jordi Sánchez-Navarro. 2013. "'The fruits of my own labour': A case study on clashing models of cocreativity in the new media landscape." International Journal of Cultural Studies 17 (6): 637-653.

Roig, Antoni, Jordi Sánchez-Navarro, and Talia Leibovitz. 2012. “¡Esta película la hacemos entre todos! Crowdsourcing and crowdfunding como prácticas colaborativas en la producción audiovisual contemporánea.” Revista Icono14 10 (1), http://www.icono14.net. Retrieved in February, 2012.

Roig, Antoni. 2013. Participatory filmmaking as media practice. International Journal of Communication. Los Angeles: University of Southern California.

Rushton, Katherine. 2013. "Music industry stages a comeback as returns to growth for first time since 1999.” The Telegraph, 26 Feb 2013. http://www.telegraph. co.uk/finance/newsbysector/mediatechnologyandtelecoms/9894851/Musicindustry-stages-a-comeback-as-returns-to-growth-for-first-time-since-1999. html.

San Cornelio, Gemma, and Edgar Gómez Cruz. 2014. "Co-creation and Participation as a Means of Innovation in New Media: An Analysis of Creativity in the Photographic Field." International Journal of Communication 8: 1-20.

Tieste, Stefanie. 2009. "The canon revisited: a chance to meet old friends (or enemies) and to make new ones”. XXVIII Le Giornate del Cinema Muto. Collegium Papers. Pordenone: Cineteca del Fruili. http://www.cinetecadelfriuli.org/gcm/ allegati/Collegium_Papers_2009.pdf\#page=102. 